\title{
Gamma Radiation Effects on Biochemical Components of Puerto Rican Mangos ${ }^{1}$
}

\author{
José Cuevas-Ruiz, H. D. Graham, and R. A. Luse
}

\section{INTRODUCTION}

The mango, Mangifera indica $L$., is one of the most widely eaten fruits in Puerto Rico where many varietics are available during a 3-month season. It is a very nutritious tropical fruit, containing ascorbic acid and carotenoids in abundant quantitics $(9,13,17) .^{2}$ The sweetness of the fruit and its surface appearance play important roles in consumer acceptance.

Mature mangos are susceptible to fungal spoilage and physiological breakdown during storage, thus have a short shelf life. Great losses of fresh ripe fruits oceur usually in both market places and ficld. Several methods are used to lengthen shelf lifo of mangos, such as picking them green but mature, and keeping them in cool storage. The fruits are eanned or frozen sometimes, but this alters or partially loses the natural flavor.

Marketing of fresh Puerto Rican mangos on the mainland of the United States is restricted because of excessive spoilage of the fresh fruit before it reaches the consumer. Delay in fruit ripening and reduction in spoilage are two important factors in prolonging shelf life. Control of these two factors would be of much significance to the Puerto Rican economy.

Fruit ripening in mangos has been retarded by ionizing radiation $(3,4$, $5,7)$. Penctrating ionizing radiation, such as gamma rays from cobalt-60, has shown great potential in the preservation of fresh fruit $(1,16)$. The fruit is exposed to intermediate deses of radiation. These reduce populations of microorganisms which cause spoilage and retard the ripening process, thereby extending shelf life. Post-irradiation refrigeration is needed usually to prolong preservation. Previous work at the Puerto Rico Nuclear Center

1 Manuscript submitted to Editorial Board November 13, 1970.

2 Research Associate, Puerto Rico Nuclear Center, operated by the University of Puerto Rico under Contract No. AT (40-1)-1833 for the U. S. Atomic Energy Commission; Professor of Chemistry, Mayagüez Campus, University of Puerto Rico; and Senior Scientist, "on leave with the International Atomic Energy Agency, Vienna, Austria," respectively. The authors wish to thank Mr. W. Pennock, Horticulturist, and Dr. Bernardo G. Capó, Technical Consultant, University of Puerto Rico, Agricultural Experiment Station, Mayagüez Campus, Rio Piedras P.R., to Mr. Pennock for his kindness in providing mango fruits for this study and to Dr. Capó for his valuable cooperation in running the statistical analysis. Thanks are due also to Dr. F. K. S. Koo, Head, Tropical Agro-Sciences Division, Puerto Rico Nuclear Center, for reviewing the manuseript, and to Miss Carmen Asencio, Research Assistant, for technical assistance. 
showed that mangos treated with $75 \mathrm{Krad}$ of gamma radiation had an extended shelf life $(3,7)$.

The Agricultural Experiment Station of the University of Puerto Rico has introduced a large number of exotic mango varieties with great adaptability to various tropical climates. The genetic and agronomic history of these varieties are known. The effect of gamma irradiation on the biochemical components of some of these well-characterized mango varieties is the basis of this report.

\section{MATERIALS AND METHODS}

Fruit of the mango varieties Sensation, Eldon, Keitt, Fent and Rubi, presently considered to have most marketing potential by Pennock (15), were obtained from the Fortuna Substation of the Agricultural Experiment Station, University of Puerto Rico. Full-green but mature-stage fruits were collected the day before irradiation. All fruits of each variety were collected from a single tree. Fruits were graded in the laboratory to size and surface color. Those bruised or otherwise defective were excluded. They then were divided into five groups of eight or 14 mangos each, depending on size. The fruit then was exposed in groups to $2 \overline{5}, 50,7 \overline{5}, 100$ or 150 Kirad doses of gamma radiation from a cobalt-60 source at the Puerto Rico Nuclear Center, Mayagüez (11), at a dose rate of $1.3 \mathrm{Krad} / \mathrm{min}$.

The irradiated fruit and non-irradiated controls were stored at $68^{\circ} \mathrm{F}$. in a constant temperature chamber. Extent of ripening was noted at intervals and observations made for appearance of skin blackening or other defects due to exposure to irradiation. Single fruits from each treat ment were withdrawn at the same time and analyzed for ascorbic acid (vitamin C), total carotenoids, total acidity and total carbohydrates. Samples from the edible portion of each fruit were analyzed in triplicate in $t$ wo different replications. Ascorbic acid content was determined by titration with 2,6-dichlorobenzenoneindiphenol dye, as described by Gyorgi ( 8 ). Total arotenoids were determined by the method described in A.O.A.C. (14). Total acidity was determined by titration with standard $0.1 \mathrm{~N} \mathrm{NaOH}$. Total carbohydrate content was determined by the anthrone method (12).

\section{IRESULTS AND DISCUSSION}

Results of only the 75-Krad treatment and non-irradiated controls are being reported here because that dose level resulted in maximum extension of shelf life. Table 1 summarizes ascorbic acid levels as a function of dose and storage time for the five varieties. Considerable vatriation was noted among the varieties in the content of aseorbie ared the day of irradiation (day zero). The highest ascorbie acid level was found in varieties Sensation and Eldon, the lowest in Kent. These findings agree with those of Iguina de 
TABLE 1.-Effects of 75-Krad gamma irradiation on the ascorbic acid conlent of mango fruits

\begin{tabular}{lcccc}
\hline \multicolumn{5}{c}{ Ascorbic acid content, as mg./100 g. pulp } \\
\cline { 3 - 5 } Variety & $\begin{array}{c}\text { Radiation dose, } \\
\text { in Krads }\end{array}$ & \multicolumn{4}{c}{ Storage time, in days } \\
\cline { 3 - 5 } & & 0 & 5 & 11 \\
\hline \multirow{2}{*}{ Sensation } & 0 & 56.0 & 46.5 & 49.2 \\
Eldon & 75 & 66.8 & 52.1 & 45.3 \\
& 0 & 56.2 & 46.6 & 45.1 \\
Keitt & 75 & 44.8 & 56.6 & 43.7 \\
& 0 & 53.0 & 53.3 & 24.7 \\
Rubi & 75 & 38.0 & 38.9 & 22.7 \\
& 0 & 39.6 & 25.3 & 19.0 \\
Kent & 75 & 37.4 & 27.8 & 19.8 \\
& 0 & 29.3 & 32.9 & 29.6 \\
& 75 & 23.9 & 29.6 & 24.2 \\
\hline
\end{tabular}

TABLE 2.-Effects of 75-Krad gamma irradiation on the tolal carolenoid content of mango fruils

\begin{tabular}{lcrrr}
\hline \multicolumn{5}{c}{ Total carotenoid content, as $\mu \mathrm{g} . / \mathrm{g}$. pulp } \\
\cline { 3 - 6 } Variety & $\begin{array}{c}\text { Radiation dose, } \\
\text { in Krads }\end{array}$ & \multicolumn{4}{c}{ Storage time, in days } \\
\cline { 3 - 6 } Sensation & 0 & 97 & 5 & 11 \\
Eldon & 75 & 120 & 57 & 225 \\
& 0 & 55 & 124 & 181 \\
Keitt & 75 & 53 & 51 & 172 \\
& 0 & 150 & 158 & 201 \\
Rubi & 75 & 121 & 122 & 233 \\
& 0 & 74 & 131 & 184 \\
Kient & 75 & 61 & 100 & 113 \\
& 0 & 209 & 304 & 247 \\
& 75 & 260 & 330 & 183 \\
\hline
\end{tabular}

George et al. (9) who also reported varietal differences in ascorbic acid content for non-irradiated mangos. There was no appreciable difference after the 5- and 11-day post-irradiation storage periods between ascorbic acid levels of irradiated and non-irradiated fruits.

The total carotenoid content of the five varieties of mangos is shown in table 2, again as a function of radiation dose and storage time. It is clear that the level of carotenoids increased in all samples, except those of Sensation at day-5 and Kent at day-11, as storage time increased. This is consistent with the finding that the carotenoid content increases as fruits ripen (6). A varietal difference in total carotenoids exists in the five varieties, with 
TABLE 3.-Effects of 75-Krad gamma irradiation on the carbohydrate content (sugar) of mango fruils

\begin{tabular}{lrrrrr}
\hline \multicolumn{5}{c}{ Carbohydrate content, as g./100 g. pulp } \\
\hline \multirow{2}{*}{ Variety } & $\begin{array}{c}\text { Radiation dose, in } \\
\text { Krads }\end{array}$ & \multicolumn{4}{c}{ Storage time, in days } \\
\cline { 3 - 5 } & 0 & 0 & 5 & 11 \\
\hline \multirow{2}{*}{ Sensation } & 75 & 12.8 & 15.9 & 18.2 \\
Eldon & 0 & 6.9 & 15.5 & 17.0 \\
& 75 & 7.4 & 15.2 & 19.0 \\
Keitt & 0 & 9.4 & 22.0 & 30.2 \\
& 75 & 8.8 & 21.9 & 29.8 \\
Rubi & 0 & 9.0 & 17.4 & 23.0 \\
& 75 & 12.4 & 19.4 & 22.5 \\
Kent & 0 & 12.8 & 21.6 & 26.0 \\
& 75 & 10.9 & 18.4 & 19.5 \\
\hline
\end{tabular}

Kent showing highest content. Irradiation at a 75-Krad dose appears to have no significant effect on the content of these pigments, as indicated by statistical analysis of the data.

The most important biochemical change taking place during fruit maturation is the increase in the amount of sugar (carbohydrates). During ripening, the starch content of the fruit falls quickly while the sugars content increases. The content of anthrone-positive carbohydrates for the five varieties is presented in table 3. An increase of total carbohydrates expressed as glucose, as the fruits ripen during storage, is clearly indicated for all varieties. The data shows that no effect of irradiation occurred on the carbohycrate content at the several storage times.

The increase of sugar content with storage time and ripening was reflected in acid content (see table 4). The acidity of the fruit normally decreases as the sugar content increases, thus giving a higher sugar to acid ratio, as shown in table $\tilde{5}$. This increase occurred in all five varieties, with Eldon, Keitt and Rubi having average sugar/acid ratios of about 6 at day zero, 15 at day 5 , and 15 to 38 at day 11 . Kent and Sensation showed a lesser increase in this ratio, with values of 12 increasing to about 15 for the former and of about 25 increasing to about 35 for the latter. There was little or no irradiation effect on the sugar/acid ratio within 5 days of storage in Eldon and Kent. The effect was notable in Sensation and Keitt, in which the sugar/acid ratio increased faster than in the controls. In Rubi, the ratio in the irradiated material increased more slowly than in the control. On the 11th day of storage, irradiated fruits, excepting Keitt, tended to have a lower ratio than the controls, indicating the radiation-induced delay in ripening. 
TABLE 4.-Effects of 75-Krad gamma irradiation on the tolal acidily of mango fruils

\begin{tabular}{lcccc}
\hline \multirow{5}{*}{ Variety } & Total acidity, expressed as ml $0.1 \times$ NaOH/100 g. pulp \\
& $\begin{array}{c}\text { Radiation dose, in } \\
\text { Krads }\end{array}$ & \multicolumn{4}{c}{ Storage time, in days } \\
\cline { 3 - 5 } & & 0 & 5 & 11 \\
\hline \multirow{2}{*}{ Sensation } & 0 & 0.34 & 0.51 & 0.48 \\
Eldon & 75 & 0.62 & 0.56 & 0.58 \\
& 0 & 1.45 & 1.30 & 0.51 \\
Keitt & 75 & 1.11 & 1.02 & 0.69 \\
& 0 & 1.24 & 1.38 & 1.31 \\
Rubi & 75 & 1.03 & 0.95 & 1.17 \\
& 0 & 1.98 & 1.10 & 0.60 \\
Kent & 75 & 2.02 & 1.54 & 1.49 \\
& 0 & 1.05 & 1.44 & 1.51 \\
& 75 & 1.01 & 1.35 & 1.57 \\
\hline
\end{tabular}

TAнЕ 5.- E.fecls of $75-K$ rad gamma irradialion on the sugar to acid ralio of mango fruils

\begin{tabular}{|c|c|c|c|c|}
\hline \multicolumn{5}{|c|}{ Sugar/acid ratio } \\
\hline \multirow{2}{*}{ Variety } & \multirow{2}{*}{$\begin{array}{l}\text { Radiation dose, in } \\
\text { Krads }\end{array}$} & \multicolumn{3}{|c|}{ Storage time, in days } \\
\hline & & 0 & 5 & 11 \\
\hline \multirow[t]{2}{*}{ Sensation } & 0 & 28.2 & 25.9 & 39.2 \\
\hline & 75 & 20.6 & 28.4 & 31.4 \\
\hline \multirow[t]{2}{*}{ Eldon } & 0 & 4.8 & 11.9 & 33.3 \\
\hline & 75 & 6.7 & 14.9 & 27.5 \\
\hline \multirow[t]{2}{*}{ Keitt } & 0 & 7.6 & 15.9 & 23.1 \\
\hline & 75 & 8.5 & 23.1 & 25.5 \\
\hline \multirow[t]{2}{*}{ Rubi } & 0 & 4.5 & 15.8 & 38.3 \\
\hline & 75 & 6.1 & 12.6 & 15.1 \\
\hline \multirow[t]{2}{*}{ Kent } & 0 & 12.2 & 15.0 & 17.2 \\
\hline & 75 & 10.8 & 13.6 & 12.4 \\
\hline
\end{tabular}

The ripening process was delayed to 7 days in irradiated mango fruits. No adverse effects, such as skin discoloration, were observed at any radiation dose employed. Fungus growth was controlled effectively by the radiation treatment; non-irradiated cont rols were heavily infected by the 11th day in storage. This finding is consistent with previous investigations indicating that gamma radiation prevents fungus spoilage in fresh fruit $(1,2,10,18)$.

The results of the present study indicate that radiation pasteurization is feasible for the tropical fruit mango. The investigation confirms that gamma irradiation at a 75-Lírad dose produces no appreciable effect on the biochemical components (ascorbic acid, carotenoids, carbohydrates, or acidity) in mango. 
A statistical analysis was made of the data obtained for the various constituents determined in all the varieties to substantiate general observation. The results indicate significant differences exist between varieties with respect to content of ascorbic acid, total carotenoids, carbohydrates, and total acidity. Storage time also had a significant influence on all these constituents, except acidity. Our statistical analyses, however, show that irradiation treatment had no significant influence on any of the biochemical components determined. This appears to confirm the principal function of irradiation merely as a retardation of ripening without significant destruction of valuable nutrients.

\section{SUMMARY}

The effects of gamma radiation were investigated on the eontent of ascorbic acid, total carotenoids, total carbohydrates and titratable acidity in five varicties of mangos grown in Pucrto Rico. Irradiation with 75-Krad doses did not significantly influence biochemical components. Subsequent changes were related closely to delay in fruit ripening, and reduction of fungal spoilage, effected by the radiation pasteurization. Radiation at the 75 -Krad level extended shelf life to 7 days.

\section{RESUMEN}

Se estudiaron los efectos de la radiación gamma en cl contenido de ácido ascórbico, carotenoides totales, hidratos de carbono totales y acidez valorable en cinco variedades de mangos cultivados en Puerto Rico. La irradición con dosis de $75 \mathrm{Krads}$ no tuvo efecto significativo en los compuestos bioquímicos. Los cambios posteriores se relacionaron intimamente con la tardanza de la fruta en madurar y una reduccion en la podredumbre que los hongos causan en la fruta, como resultado de la pasteurización por irradiación. El tratamiento con 75 Krads prolongó en 7 días la duración de la fruta almacenada.

\section{LITERATURE CITED}

1. Beraha, L., Smith, M. A., and Wright, W. R., Gamma radiation dose-response of some decay pathogens, Phytopathology 50: 474-76, 1960.

2. Cuevas-Ruiz, J., Radiopasteurization of mangoes, M. S. thesis, Mayagüez Campus, University of Puerto Rico, 1966.

3. Cuevas-Ruiz, J., Luse, R. A., and Graham, H. D., Preservation of tropical foodstuffs by irradiation, Proc. Caribbean Food Crops Soc., Vol. VI, 112-19, 1968.

4. Dennison, R. A., Effects of low level irradiation upon the preservation of food products, Conf. 661017, T.I.D., U.S. Atomic Energy Commission, 55-7, 1966.

5. Dharkar, S. D., and Sreenivasan, A., Irradiation of tropical fruits and vegetables, Fond Irradiation, I.A.E.A., Vicuna, Aust ria, 6i35-50, 1961 .

6. Cioodwin, 'T. W., The Carotenoids, Chemicnal Publishing, Co., New York, N. Y., 1054.

7. Graham, II. D., and Iuse, R. A., Raliation preservation of tropical fonds, Food Irradiation Contractors Meeting, T.I.1.-4500, 102-6, 1967. 
8. Gyorgi, P., Vitamin Methods, Vol. 1, Academic Press, Inc., New York, N. Y. pp. 266-7, 1950.

9. Iguina de George, L. M., Collazo de Rivera, A. L., Benero, J. R., and Pennock, W., Provitamin A and vitamin $C$ contents of several varieties of mango grown in Puerto Rico, J. Agr. Univ. P. R., 53 (2) : 100-5, 1969.

10. Jiravatana, V., Cuevas-Ruiz, J., and Graham, H. D., Extension of storage life of papayas grown in Puerto Rico by radiation treatments, J. Agr. Univ. P.R., 54 (2): 314-9, 1970.

11. Linden, D. B., and Teas, H. J. A multipurpose $\mathrm{Co}^{60}$ gamma irradiation facility, Intern. J. Appl. Radiation and Isotopes, 16: 661-5, 1965.

12. Morris, D. L., The quantitative determination of carbohydrates with Dreywood's anthrone reagent. Sci. $107: 254,1948$.

13. Munsell, H. E., Ascorbic acid content of the mango in relation to variety, Food Res., 11: 95-8, 1946.

14. Official Methods of Analyses of the Association of Official Agricultural Chemists, 10th ed., Washington, D.C., 1965.

15. Pennock, W., An evaluation of twenty-five varieties of mangoes for commercial planting in Puerto Rico, Proc. Caribbean Food Crops Soc., Vol. V, 116-21, 1967.

16. Salunke, D. K., Gamma radiation effects on fruits and vegetables, Econ. Bot. 15 : 128-56, 1961.

17. Singh, L. B., The Mango, Interscience Publishers, Inc., New York, N.Y., 1960.

18. Sommer, N. F., and Maxie, E. C., Recent research on the radiation of fruits and vegetables, Food Irradiation, I.A.E.A., Vienna, Austria, 517-87, 1966. 